\title{
Future forage plants for hill country systems
}

\author{
S.N. NICHOLS ${ }^{1}$, J.R. CRUSH ${ }^{1}$, C.C. EADY ${ }^{2}$, M.J. FAVILLE ${ }^{3}$, K. GHAMKHAR ${ }^{3}$ and D.R. WOODFIELD ${ }^{3,4}$ \\ ${ }^{l}$ AgResearch, Ruakura Research Centre, Private Bag 3123, Hamilton, New Zealand \\ ${ }^{2}$ New Zealand Agriseeds Ltd., 2547 Old West Coast Road, RD1, Christchurch, New Zealand \\ ${ }^{3}$ AgResearch, Grasslands Research Centre, Private Bag 11008, Palmerston North, New Zealand \\ ${ }^{4}$ PGG Wrightson Seeds Ltd., Kimihia Research Centre, P.O. Box 175, Lincoln, New Zealand \\ shirley.nichols@agresearch.co.nz
}

\begin{abstract}
The issues currently limiting the performance of forage plants in hill country are largely unchanged from preceding decades. Low soil $\mathrm{pH} /$ high aluminium, low soil phosphate and low soil moisture or summer dry conditions are all ongoing problems. Furthermore, predicted climatic changes in many regions will only intensify soil moisture stress. Forage breeding programmes in the 1970s and 1980s delivered a range of cultivars that improved hill country productivity, but small market size for seed has not been conducive to widespread success of these cultivars or to provision of dedicated plant breeding programmes for these farming systems. Intensification is however driving renewed interest in forages for hill country. A wide range of genetic resources is now available to breeders for better adaptation to these conditions. These include large germplasm collections within existing species, germplasm for interspecific crosses, and potential "new" species which have evolved appropriate adaptations at their point of origin. Advances in genomic technologies offer potential to provide accelerated, more targeted selection of germplasm. This would be particularly valuable for traits that are under complex genetic control, or are more difficult to visually assess, such as physiological and root characteristics. Adjustments in pasture management will be necessary to capture the full potential of new germplasm, while tools to improve pasture establishment and renewal (e.g. new herbicide tolerant brassicas) are also needed to enable its successful introduction. The amalgamation of seed companies into large international enterprises adds potential scale to what has traditionally been a localised issue, making the commercial proposition of developing and marketing such specialised products more attractive. These developments, combined with improved seed distribution technologies, should provide a great opportunity for future hill country farming.
\end{abstract}

Keywords: germplasm, phosphorus, aluminium, drought, genomic selection, cultivars

\section{Key messages}

- Germplasm resources are available to develop cultivars for hill country
- New approaches to breeding offer the potential to increase genetic variation for, and selection of, traits of interest

- Despite the potential offered by plant breeding, commercial realities are a major factor determining the availability of cultivars for hill country.

\section{Introduction}

There is a long history of research on New Zealand hill country that has included germplasm evaluation, for example the series of papers introduced by Williams et al. (1990) and Stevens et al. (1993). This has resulted in a range of grass and legume cultivars for use in hill country (Table 1). In addition to these, a range of browse shrubs and alternative species such as sheeps burnet and crown vetch for revegetation and grazing purposes, plus various Australian-bred subterranean clover (Trifolium subterraneum) cultivars, have been used in hill country. However, with the notable exception of Maku lotus, Wana cocksfoot, subterranean clover and white clover, very few cultivars have been commercially successful due to the limited market size. This is a symptom of low rates of pasture renewal in hill country, due to difficulties in establishing new pastures on hill slopes, and few demonstrations of the economic benefits of pasture renewal. Therefore few breeding programmes have targeted hill and high country, selecting instead for more productive environments while maintaining some evaluation under hill country systems.

In hill pastures, growing more legumes does stimulate animal production directly via forage quality, and also indirectly through higher rates of nitrogen $(\mathrm{N})$ fixation which increase soil fertility and, consequently, the growth of grasses and predominance of higher forage quality grass species. The main limitations to grass and legume growth in hill pastures are low soil phosphorus (P) levels, phytotoxic levels of aluminium (Al) in the subsoil of acid soils, and moisture stress.

The beneficial effects of higher and more frequent $\mathrm{P}$ fertiliser application rates to hill country on growth of clover and higher quality grasses are well understood. In practice, increases in stocking rate and cattle:sheep ratios need to accompany the fertiliser inputs to maintain sward quality and maximise returns on the investment (Clark et al. 1982; Lambert et al. 1982). 
Different slopes and aspects influence animal grazing patterns, leading to variable herbage utilisation and nutrient transfer in excreta (Gillingham \& During 1973), and these can also influence legume vigour.

Subsoil Al toxicity in acid soils inhibits rooting depth and therefore the volume of exploitable soil water. Raising soil $\mathrm{pH}$ by surface applications of lime - the only option on uncultivable hill country - is unlikely to reduce subsoil Al levels without continued, regular lime applications (Moir \& Moot 2014). There is variation between and within forage species for tolerance of Al toxic soils (Crush \& Caradus 1992; Wheeler et al. 1992) but few Al-tolerant cultivars have been released for hill country (e.g. Kingston perennial ryegrass, Stewart 2006).

Hill country is loosely classified as wet or dry, with northern aspects typically drier than southern aspects, but the intensity and consistency of drought is critical. Summer drought can occur in all classes of hill country and resident clovers tend to be drought-avoiding, early flowering perennial white clover ecotypes, or annuals like subterranean clover (MacFarlane \& Sheath 1983). Looking forward, we must keep in mind that climate-change models predict reduced precipitation and increased evaporation, and thus longer summer moisture deficits for the eastern parts of both the South and North Islands (IPCC 2013), which include hill country areas.

In addition, land use changes over the past decade have seen beef and lamb finishing and dairy grazing move onto land classes previously used for breeding stock. This intensification of land use has increased demand for more productive forages and for better methods of pasture renewal in hill and high country.

Table 1 Forage cultivars and pre-release cultivars developed for New Zealand hill and high country use.

\begin{tabular}{|c|c|c|c|}
\hline Common name & Species & Cultivar & Year of release \\
\hline \multirow[t]{2}{*}{ Birdsfoot trefoil } & Lotus corniculatus & Grasslands Goldie & 1989 \\
\hline & & G46 (dryland selection) & Not released \\
\hline \multirow[t]{3}{*}{ Lotus } & Lotus pedunculatus & Maku & 1974 \\
\hline & & Grasslands Sunrise & 1991 \\
\hline & & Grasslands Trojan & 2003 \\
\hline Caucasian clover & Trifolium ambiguum & Endura & 1995 \\
\hline Alsike clover & Trifolium hybridum & G50 & Not released \\
\hline Zig-zag clover & Trifolium medium & G41 & Not released \\
\hline \multirow[t]{5}{*}{ White clover } & Trifolium repens & Grasslands Tahora & 1982 \\
\hline & & Prop & 1988 \\
\hline & & Prestige & 1990 \\
\hline & & Grasslands Nomad & 2000 \\
\hline & & Tahora II & 2007 \\
\hline Browntop & Agrostis capillaris & Grasslands Muster & 1991 \\
\hline Smooth brome & Bromus inermis & Grasslands Tiki & 1985 \\
\hline Upland brome & Bromus sitchensis & Grasslands Hakari & 1985 \\
\hline Pasture brome & Bromus valdivianus & Bareno & 1999 \\
\hline Crested dogstail & Cynosurus cristatus & Grasslands Aspiring & 1988 \\
\hline \multirow[t]{3}{*}{ Cocksfoot } & Dactylis glomerata & Grasslands Wana & 1980 \\
\hline & & Grasslands Excel & 1999 \\
\hline & & Safin & 2012 \\
\hline \multirow[t]{3}{*}{ Yorkshire fog } & Holcus lanatus & Massey Bassyn & 1962 \\
\hline & & Melita & 1994 \\
\hline & & Forester & 1998 \\
\hline \multirow[t]{3}{*}{ Perennial ryegrass } & Lolium perenne & Kingston & 1995 \\
\hline & & Rohan & 2013 \\
\hline & & G30 & Not released \\
\hline Paspalum & Paspalum dilatatum & Grasslands Raki & 1979 \\
\hline Phalaris & Phalaris aquatica & Grasslands Maru & 1960 \\
\hline
\end{tabular}


In this paper we discuss options for the identification and exploitation of future germplasm carrying traits to mitigate the challenges inherent in hill country pastures, and issues which the broader industry must address to ensure successful commercialisation and adoption of new cultivars.

\section{Traits to improve adaptation to hill country}

Unsurprisingly, root characteristics are a major contributor to improved adaptation to soil-based limitations such as low $\mathrm{P}, \mathrm{Al}$ and drought. Root traits known to increase $\mathrm{P}$ acquisition include fine root diameter, high root length density, and high root hair length and density (Simpson et al. 2014). Roots of some plants also exude organic acids and phosphatase enzymes which mobilise P from the soil, especially under $\mathrm{P}$ deficient conditions (Simpson et al. 2014). The pasture species used in New Zealand have not been assessed for their ability to exude the compounds associated with P mobilisation. Physiologically, plants with lower critical $\mathrm{P}$ concentrations, and thus higher phosphorus use efficiency, will have better yields at low soil P levels and there are some species with inherently low tissue $\mathrm{P}$ concentrations, such as Holcus lanatus and Lotus corniculatus (Simpson et al. 2014).

Both the physiological effects of Al toxicity and the physiological mechanisms for $\mathrm{Al}$ resistance are complex (Kochian et al. 2004; Yang et al. 2013). Numerous root properties are involved, including cell wall extensibility and permeability, root hydraulic conductance, and water permeability. Exclusion of Al from roots includes exudation of the organic acids which are also known to mobilise P (Kochian et al. 2004). Resistance mechanisms vary with species and, in some crops at least (e.g. rice and maize), are controlled by multiple genes (Kochian et al. 2015). The physiological effects of $\mathrm{Al}$ and mechanisms of resistance are widely studied in crops, but less so in forage species.

A range of root traits also influence the ability of plants to acquire water. Among crop species, increasing rooting depth, and thus accessing deeper soil moisture, is a major breeding target. Due to the effects of $\mathrm{Al}$ on root penetration, improving $\mathrm{Al}$ tolerance of hill country germplasm would also contribute to drought resistance and tolerance of low soil moisture. However, there are also many complex physiological and biochemical traits which contribute to drought resistance, such as the production of protective compounds. In annual species, traits associated with seed production and regeneration are important for persistence in dryland environments, and are likely to become more important with changing climate (Revell et al. 2012).

The success of Safin and Wana cocksfoot and Maru phalaris was their ability to withstand the combined effects of moisture stress and hard grazing.
Unfortunately, little selection work has been done in the last 20 years to improve on this adaptation. Similarly, the success of Maku lotus and other Lotus pedunculatus cultivars in moist hill country can be attributed to its excellent $\mathrm{Al}$ resistance and tolerance of low fertility, acidic soils. Massey Basyn and other cultivars of Yorkshire fog have also performed best under these conditions. There is also potential for pyramiding traits, particularly in interspecific hybrids, where the additive impact of several traits has a greater effect than either trait on its own. For the major limiting factors in hill country, combined tolerances and additive traits are key factors.

Traditionally, selection for improved resistance/ tolerance of these soil limitations has been carried out by assessing agronomic performance, thus incorporating multiple stress resistance. Identification of the traits contributing to high performance under these conditions could provide useful information to underpin long-term performance gains. However, direct selection for traits associated with roots, physiology and biochemistry is difficult, expensive and time consuming - especially under field conditions. Conversely, selection for some traits under glasshouse conditions can be misleading, as environmental complexities may eliminate any advantage when transferred to the field, e.g. tolerance of low $\mathrm{P}$ and high $\mathrm{Al}$ in white clover (Caradus et al. 2001; Caradus \& Dunn 2000). Furthermore, selecting for traits in isolation may fail to incorporate other characteristics important for adaptation or general agronomic performance. An approach which combines these methods is required, to focus beneficial characteristics in agronomically adapted material. Genomics-based technologies may provide tools which increase the accuracy and ultimate success of selections. New automated phenotyping methods also offer potential for large-scale, cost-effective field-based screening of some traits, such as biomass (LiDAR, Light Detection and Ranging) and feed quality (NIR spectroscopy or hyperspectral imaging).

\section{Current breeding focus}

There are active forage breeding programmes in New Zealand that evaluate material in hill country as a routine part of the development process, however, the limited market size has resulted in few targeted breeding programmes for hill country. Elite selections from ryegrass, cocksfoot, clover (white, red and interspecific hybrids), chicory, plantain and lotus breeding programmes are evaluated, but only in white clover is there a specific programme targeting selection in hill country environments. However, there is little evidence of major re-ranking in the performance of perennial ryegrasses when grown in hill country compared to lowland pastures. Higher tiller densities 
contribute to better persistence of ryegrass and Rohan has been bred for lower yields, high tiller density and lateral spreading ability, to give improved adaption to adverse, summer dry conditions of hill country (C. Inch pers. comm.).

Fertility and grazing management are strong drivers of success, along with the ability to achieve successful pasture renewal. Improved pasture renewal through use of double-spray with herbicide, to effectively control the resident grass (Kerr et al. 2015), and either a brassica or forage cereal crop has allowed use of plantain and chicory in rolling to flat land, either as a pure sward or in combination with white clover. This allows hill country farmers to capture all of the improvements from breeding programmes in these species and in improved forage grasses. The advent of herbicide tolerant (HT) brassicas (Dumbleton et al. 2012) has also created new opportunities for pasture renewal in hill country.

In addition to the predicted climatic changes, plant breeding for hill country must also consider potential regulatory constraints around nutrient application and sediment loss, particularly in sensitive catchments. This is already occurring in some regions, such as the Lake Taupo catchment, and new research and pre-breeding on plants for improved nutrient-use efficiency and nitrate interception is a direct response to these changes. Potential impacts on nutrient losses and erosion from intensification in hill country, resulting from changes in both land use and management practices, must be considered in the broader context of the future plants that will be required.

\section{Genetic resources}

The Margot Forde Forage Germplasm Centre (MFFGC), houses New Zealand's largest seed bank, with a collection of $>110000$ forage accessions. The focus on high fertility environments and high performing species over the past 25 years means that minimal exploration of new genetic resources has occurred for hill country. The current germplasm collection includes breeding lines, commercial cultivars, and wild populations collected from regions as diverse as the islands of the Mediterranean Sea and the mountains of Tajikistan and Kazakhstan. These wild collections are mostly untapped and have exciting potential given the predicted changes in rainfall and evaporation for New Zealand hill country. Improved molecular, phenotyping and GIS tools for germplasm rationalisation and core collection development now enable researchers and breeders to focus on manageable pools of germplasm, with maximum available diversity.

Currently, there are more than 2200 species, collected from over 100 countries, in the MFFGC. The collection dates back to the 1940s but regular collection trips continue to be a priority. This broad range of eco- geographical distribution provides a great source of genetic diversity for trait and gene discovery and some accessions may have better adaptation to environments that require traits of interest for hill country. The characterisation of these genetic resources in New Zealand hill country should be a strategic priority.

\section{Novel species and new germplasm for desirable traits}

Adaptation to predicted climatic changes (IPCC 2013) requires a more proactive and innovative approach than in the past. This paper covers just a few examples of new species with potential adaptation to future climate challenges, or existing germplasm where genetic resources can be further exploited. Subterranean clover (Trifolium subterraneum) has been extensively used across New Zealand hill country environments (Smetham 2003) and is the best self-regenerating annual clover species. Currently, all commercial subterranean clover seed is imported from Australia with cultivars varying in flowering date and hardseededness rating. The best options for New Zealand dry hill country are later flowering cultivars of ssp. subterraneum and brachycalycinum, to increase the vegetative growth period. These two subspecies need a minimum annual rainfall of $300 \mathrm{~mm}$, and therefore should be considered where white clover performs poorly due to summer-dry conditions. For wetter hill country with poorly drained soils, and some summer rainfall, ssp. yanninicum might also be an option as it is waterlogging tolerant but susceptible to drought. More information on the potential development of subterranean clover for New Zealand is provided elsewhere in this publication (Ghamkhar et al. 2016).

Looking to the future, there is a need to investigate the use of different species for resilience under changing climatic conditions in some areas. Biserrula (Biserrula pelecinus) is a recently domesticated legume species with potential to make a difference to the productivity of hill country. High levels of drought resistance on acidic sandy soils in Sardinia (Loi et al. 1997), high production of small seeds, easy harvesting and processing, and a large and persistent seed bank in the soil (Malo \& Suarez 1995) suggest it may have potential in New Zealand's dry hill country regions. It has deep roots, over $2 \mathrm{~m}$ in unrestricted soils, and so is more capable of accessing water than white clover. Biserrula can grow in regions with as low as $350 \mathrm{~mm}$ annual rainfall, has an acid-tolerant rhizobium which can persist and give excellent nodulation on soils with a $\mathrm{pH}$ as low as $4.2\left(\mathrm{CaCl}_{2}\right)$ (Loi et al. 2015), and may have better root traits for $\mathrm{P}$ acquisition than species such as subterranean clover and lucerne (Yang et al. 2015). Furthermore, under heavy grazing, it adopts a prostrate growth habit as a defensive mechanism against over- 
grazing. The current Australian cultivars are hardseeded and probably less suitable for most New Zealand environments (Ghamkhar et al. 2016), with the possible exception of some north facing slopes in parts of the east coast. Some accessions of biserrula, including the Australian cultivar Casbah, can cause photosensitivity in livestock when grown in monoculture. The identity of compounds causing photosensitivity is unknown and requires further screening (Swinny et al. 2015). A core collection of biserrula germplasm in Australia (Ghamkhar et al. 2013) is accessible for selection of suitable lines for New Zealand hill country.

Some species of Astragalus L. (e.g. Cicer milkvetch) have shown potential in dry hill country (Douglas et al. 1996). This legume genus comprises c. 3000 species and, while a number of these species are toxic for livestock (Rios \& Waterman 1997), some others may be suitable for New Zealand hill country. Astragalus cicer (Cicer milkvetch) is among the most promising species, growing in areas with annual rainfall as low as $350 \mathrm{~mm}$ in North America (Acharya et al. 2006; Townsend 1993) and Europe (Aniszewski 2004). It also persists well in less nutrient-rich or disturbed soils. Other species that have not been tested in New Zealand include Astragalus adsurgens, which is widely used as a forage legume in semiarid China, Mongolia, Russia, Japan, and Korea (Guan et al. 2013). There are also $>600$ species of Astragalus in Iran, of which a few have high nutritive value and metabolisable energy such as $A$. podolobus, A. jolderensis and $A$. onobrychis. (Hosseini et al. 2010; Shadnoush et al. 2015). However, Astragalus species have hard seed, so selection for more soft seeded accessions would be a priority for New Zealand.

\section{Future collection of new germplasm}

Identifying novel species for future hill country systems is only the first step. Equally important is the collection and screening of germplasm for promising accessions. This will need support and coordination from Government, the farming community and the seed industry. Finding gaps in the germplasm is extremely important for species with existing pre-breeding and breeding work and literature, such as subterranean clover (Ghamkhar et al. 2015). For species with little pre-breeding work and literature, collection must be focused on the centres of origin and/or diversity of the species of interest, and regions with similar climatic conditions to our target zones. This will require planning for germplasm collection expeditions to southern Europe, the United States and the Middle East to develop a broad base for every species of interest. It should be noted that use of new legume species will require research on appropriate rhizobial strains.

\section{Regulatory restrictions}

Subterranean clover has been grown in New Zealand hill country since the early 1900 s. This will make further research on the species simple from the regulatory point of view, but other species are a different story. For example, field research on biserrula in New Zealand, without controls, is prohibited as it is a new organism under the HSNO Act. However, a release application by Kiwi Seed Co. Ltd. for a field trial of biserrula, on the grounds of its drought tolerance, was approved by the EPA with controls (no flowering and no seed setting) in 2007. Also, while A. cicer and A. adsurgens are permitted in the field, the other three species of interest are not listed in the MPI's Plant Biosecurity Index as "Basic". These biosecurity restrictions will impose increased cost and complexity in testing new species in New Zealand.

In the late 1990s and early 2000s, Australian researchers and germplasm centres imported and screened many new pasture species, including biserrula, based on regional climatic conditions and soil types. This has now resulted in more options for Australian farmers, particularly in Western Australia and New South Wales. Current restrictions on new species in New Zealand will, by contrast, limit preparation for future challenges, such as climate change. Approval of small scale pilot experiments, even under strict controls, would provide preliminary data to inform regulatory organisations of the potential of new species. However, seed setting and seed yield are important traits which, for example, cannot be studied in biserrula under current restrictions. Thorough weed risk assessments for any potential new species, including the suggested species of Astragalus and biserrula, would also assist the decision making of regulatory authorities.

\section{Interspecific hybridisation}

Interspecific hybridisation between common pasture species and their wild relatives can be utilised to produce improved germplasm. In Europe, crosses between Lolium and Festuca species have been developed specifically to introduce persistence and stress resistance traits from fescues into ryegrasses (Humphreys et al. 1997; Thomas et al. 2003). So far, Festuloliums have not been tested in New Zealand hill country but have performed poorly in other New Zealand regions. In Australia, breeding to introduce Al tolerance from Phalaris arundinacea into P. aquatica has produced an acid soil/Al tolerant phalaris cultivar (Culvenor \& Simpson 2014). Given the proven performance of Maru phalaris in NZ hill country (Stevens et al. 1989) there is further scope to improve the adaptation of forage grasses to hill country soils.

Research on Trifolium interspecific hybrids has created potential to improve the adaptation of white 
clover to hill country conditions, and produce other novel, adapted genetic combinations. Molecular biology has identified the Trifolium species closely related to white clover (Ellison et al. 2006). Most of these species have now been crossed, directly or indirectly, with white clover and possess a range of valuable traits (Williams 2014). The first commercially available interspecific hybrid clover cultivar, AberLasting, is a cross between Caucasian clover (T. ambiguum) and white clover, bred in the United Kingdom for improved drought resistance. The remaining hybrid combinations are a relatively unexplored source of novel traits and genetic variation for adaptation to hill country.

The hybrids between white clover and both T. occidentale and T. uniflorum look the most promising to date for New Zealand. Trifolium occidentale is from Atlantic coastal areas in Europe and has tolerance of salinity as well as low soil moisture. Trifolium uniflorum is from dry habitats with poor soil fertility in the Mediterranean region. Studies have observed reduced impacts of drought stress on dry matter production in hybrids compared with white clover (Hussain \& Williams 2014; Nichols et al. 2014b). In T. occidentale hybrids this has been attributed to a vigorous root system, while differences in physiology as well as root traits were observed in T. uniflorum hybrids (Hussain \& Williams 2014; Nichols et al. 2014b; Nichols et al. 2015). Under controlled conditions, T. uniflorum hybrids have also shown deeper rooting than white clover (Nichols 2012). Higher biomass under low external $\mathrm{P}$ supply has also been observed in some $T$. repens $\times T$. uniflorum lines, and differences in root branching patterns may explain some of these results (Nichols et al. 2014a). These traits would all be valuable in hill country germplasm, but need to be introduced to material with general adaptation to the environment and farming system. Selection for seed production traits will also be required, especially for T. uniflorum.

In Australia, research to identify close relatives of subterranean clover with low critical $\mathrm{P}$ requirements and root traits conducive to improved $\mathrm{P}$ acquisition could also lead to hybridisation of this species (Haling et al. 2015), but commercial development of breeding programmes will depend on market factors.

\section{Genomic selection for accelerated and targeted development of new cultivars}

Conventional breeding typically encompasses years of phenotypic evaluation of plants or families (Conaghan \& Casler 2011) for multiple traits, to accurately identify elite parents that will form the basis of a new cultivar. The time from conception to a cultivar entering the market is 8-15 years and the historic rate of genetic gain per unit time for forages has been moderate (Brummer \& Casler 2014; Woodfield 1999).
Genomic selection (GS) enables a breeder to predict the breeding value of an otherwise untested plant, using a genome-wide DNA fingerprint generated with singlenucleotide polymorphism (SNP) markers. Integrated in commercial plant breeding programmes, GS has the potential to increase the rate of genetic gain (Heffner et al. 2010; Simeão Resende et al. 2014) and reduce the time required for cultivar development. This is because GS shortens the breeding cycle, by allowing identification of elite plants at an early stage before key traits are expressed, and enabling increased selection accuracy for traits that are genetically complex or costly or difficult to assess conventionally. In GS, a representative 'training population' of individuals that has been both genotyped with SNP markers and phenotyped for the trait of interest, is used to develop a statistical model that predicts trait values from the SNP marker information. The statistical model can subsequently be applied to plants that have been SNP genotyped only, providing a rapid prediction of their genetic value without measuring the trait. In contrast to marker-assisted selection (MAS), which is largely confined to the use of single markers to select for traits controlled by small gene numbers (Heffner et al. 2010), in GS the effects of thousands of markers are used simultaneously, enabling prediction of complex agronomic traits affected by many genes.

Genomic selection has been employed in animal breeding programmes for several years (Hayes et al. 2013b) but, for most plant species, has only become a realistic prospect with the recent advent of low cost, high-throughput SNP marker platforms such as genotyping-by-sequencing (GBS) (Elshire et al. 2011). Genomic selection is now being investigated for forage grasses and legumes, notably perennial ryegrass and white clover, with GBS or equivalent SNP platforms as a key driver (Barrett et al. 2015; Hayes et al. 2013a; Li et al. 2015; Simeão Resende et al. 2014). Amongst forage species with potential for New Zealand summer-dry hill country, subterranean clover represents a suitable candidate for implementation of a GS breeding strategy because of its simple genetics (diploid, with an inbreeding reproductive system) and a forthcoming sequenced genome (https://www. pawsey.org.au/projects/subterranean-clover-genomicsplatform) to support GBS. Late flowering time, reduced hardseededness, increasing/decreasing burr burial and improving yield under low soil moisture conditions have been identified as traits to improve the persistence and productive performance of subterranean clover in hill country (Ghamkhar et al. 2016). The first two are quantitative traits controlled by numerous genes (Cattivelli et al. 2008; Ghamkhar et al. 2012) and, as such, breeding for improvement in these traits stands to benefit from a GS breeding strategy. 


\section{Commercial perspectives}

With about 4 million hectares of hill and high country under sheep, beef and deer grazing in New Zealand (Ministry for the Environment 2007) the prospect of developing commercial cultivars for such a potential market would seem very attractive. However, this area is fragmented into many different physical (e.g. soil types, aspect, climatic zones) and management (e.g. organic, passive, active) sub-categories to leave a plethora of different requirements that reduce commercial opportunities. This is further compromised by the difficulties (in cultivation and establishment), cost, and currently variable success of hill country sowing. These issues have meant that, on the whole, few specialist crops have been produced due to small market sizes. There are a wide range of cultivars that are used in hill country but were not specifically bred for these systems, and those that succeed have generally been shown to provide better animal productivity than the existing species. Land use change and intensification in hill country will increase demand for better species and specialist crops, and may lead to re-evaluation of lowland species for their fit to hill country environments. The expansion of dairy grazing/ replacements in hill country may also increase the affordability of management strategies (e.g. fertiliser use) that enable new and better forages to be grown. Increased uptake of these specialist varieties would drive their commercial viability.

Often the decisions to renew pasture in these 'risky' areas are based around a combination of opportunistic events, such as short-term increases in farm income, favourable weather and the chance to purchase some cheap seed. The risk balance between investment and reward is difficult for farmers to overcome, and erring on the side of caution is an easy and understandable option.

Research shows that gains can be made through pasture renewal, with recent work on two South Island hill country pasture sites demonstrating an increase of $\sim 3000 \mathrm{~kg} \mathrm{DM} / \mathrm{ha} /$ annum (Thompson \& Stevens 2011) ( $\sim 900$ according to the average FVI economic value for the lower South Island). Similar, earlier studies in the North Island gave less conclusive results but concluded: "There is now a better pasture on the trial sites than the pasture before the cropping cycle. New grass species have been established, and a better clover mix. With careful management of grazing and fertiliser, this new pasture should be maintainable for many years to come." (NZ hill country cropping and regrassing network 2003).

These benefits are only fully realised and maintained if more intensive management practices (such as more paddocks, more frequent animal movements, better utilisation and supplementary feed on hand) are also incorporated. Such practice changes will likely come over time as greater pressure is put onto hill country to improve production efficiency. These changes would also drive a greater demand for hill country specific crops, but until such time it is debateable how much effort seed companies will invest to develop such crops.

The amalgamation of many seed companies into international entities may provide a greater opportunity to develop specialist crops for hill country for three reasons: 1) Access to global hill country markets provides a greater opportunity than just a localised option; 2) Access to developed cultivars from around the world may provide opportunities to find species/cultivar 'fit' for particular niche areas; and 3) Larger seed companies have greater research capability to undertake rapid specialist re-selection, through technologies such as genomic selection, to quickly adapt existing cultivars to better suit hill country requirements. However, this is balanced by the relatively unique combination of climate, soils, farm systems and human capability in New Zealand hill country, which may limit applicability of overseas germplasm in New Zealand, or locally produced plant material elsewhere.

Thus seed companies have the capability to develop hill country-specific cultivars for New Zealand, but a sound return for this investment is unlikely to be forthcoming until the investment:reward balance for the farmer is more guaranteed. However, this requires the cultivars, technology and knowledge to increase the success of renewal, and a commitment by the farmer to manage more intensively (balanced against environmental concerns). One possible way to progress this conundrum would be the formation of public good research consortia. This could effectively kick start progress through research to assist in the development of germplasm, technologies, and a demonstration of productivity gain, thus driving demand and a market for hill country specific cultivars.

\section{Conclusion}

The ecology of New Zealand hill pastures is well understood, as are many of the plant traits required to mitigate the edaphic and climatic factors limiting clover growth. Past and current cultivars developed for hill pastures were selected for general agronomic adaptation, with no overt attempt to select for specific adaptive traits. Future cultivar development for hill pastures may rely on:

1. Making better use of the genetic variation contained in the MFFGC, so that breeders can work with species and germplasm with a wider trait range than occurs in contemporary pastures.

2. Making more use of interspecific hybrid populations to increase the variation available to breeders.

3. More targeted selection for specific traits associated 
with adaptation to hill country environments.

4. Application of genomic breeding methods to increase the speed and accuracy of the process.

However, there needs to be discussion across the broader industry to focus breeding targets to ensure successful adoption of any new cultivars. Furthermore, plant breeding is just one step in improvement of hill pastures. For farmers to have confidence that sowing new cultivars will provide economic gains there needs to be solid evidence for each main region from large scale, long-term field experiments. This sort of work will not attract funding from central Government without substantial support from sector organisations. There also needs to be fresh thinking about the technologies for establishing new cultivars on hill slopes to produce methods that are effective and economically viable. The final issue relates to seed volumes and the commercial viability of hill country cultivars. Agronomic success depends on maximising the cultivar's adaptation to local soils and climate. In the longer term, regionally adapted hill country cultivars would provide farmers with the best genetic potential for their pasture, but would not be commercially viable for current seed industry supply chains.

Trends affecting the wider industry may increase the potential for development of specific cultivars for hill country. For example, predicted changes in climate potentially enable the parallel development of drought resistant germplasm for both hill country and lowland environments. Similarly, collaborative research programmes, such as the Pastoral 21 and Pastoral Genomics consortia, in which multiple sectors invest funding for common research goals, may increase the cost effectiveness of the hill country research dollar.

\section{REFERENCES}

Acharya, S.; Kastelic, J.; Beauchemin, K.; Messenger, D. 2006. A review of research progress on cicer milkvetch (Astragalus cicer L.). Canadian Journal of Plant Science 86: 49-62.

Aniszewski, T. 2004. Legume species that have breeding potential for NE Europe. Science of Legumes 6: 256265.

Barrett, B.A.; Faville, M.J.; Nichols, S.N.; Simpson, W.R.; Bryan, G.T.; Conner, A.J. 2015. Breaking through the feed barrier: options for improving forage genetics. Animal Production Science 55: 883892.

Brummer, E.C.; Casler, M.D. 2014. Cool-season forages. pp. 33-52. In: Yield gains in major U.S. field crops. Eds. Smith, S.; Diers, B.; Specht, J.; Carver, B. American Society of Agronomy, Inc., Crop Science Society of America, Inc., and Soil Science Society of America, Inc.
Caradus, J.R.; Crush, J.R.; Ouyang, L.; Fraser, W. 2001. Evaluation of aluminium-tolerant white clover (Trifolium repens) selections on East Otago upland soils. New Zealand Journal of Agricultural Research 44: 141-150.

Caradus, J.R.; Dunn, A. 2000. Adaptation to low fertility hill country of white clover lines selected for differences in response to phosphorus. New Zealand Journal of Agricultural Research 43: 6369.

Cattivelli, L.; Rizza, F.; Badeck, F.-W.; Mazzucotelli, E.; Mastrangelo, A.M.; Francia, E.; Marè, C.; Tondelli, A.; Stanca, A.M. 2008. Drought tolerance improvement in crop plants: An integrated view from breeding to genomics. Field Crops Research 105: $1-14$.

Clark, D.A.; Lambert, M.G.; Chapman, D.F. 1982. Pasture management and hill country production. Proceedings of the New Zealand Grassland Association 43: 205-214.

Conaghan, P.; Casler, M.D. 2011. A theoretical and practical analysis of the optimum breeding system for perennial ryegrass. Irish Journal of Agricultural and Food Research 50: 47-63.

Crush, J.R.; Caradus, J.R. 1992. Response to soil aluminium of two white clover (Trifolium repens L.) genotypes. Plant and Soil 146: 39-43.

Culvenor, R.A.; Simpson, R.J. 2014. Persistence traits in perennial pasture grasses: the case of phalaris (Phalaris aquatica L.). Crop and Pasture Science 65: 1165-1176.

Douglas, G.B.; Wills, B.J.; Pryor, H.N.; Foote, A.G.; Trainor, K.D. 1996. Establishment of perennial legume species in drought-prone, North and South Island sites. Proceedings of the New Zealand Grassland Association 58: 253-257.

Dumbleton, A.; Gowers, S.; Conner, A.; Christie, M.; Kenny, P.; Mulcock, H.; Charteris, B. 2012. Cleancrop ${ }^{\mathrm{TM}}$ Brassica System: The development of herbicide resistant brassica crops for New Zealand farming systems. Proceedings of the New Zealand Grassland Association 74: 25-30.

Ellison, N.W.; Liston, A.; Steiner, J.J.; Williams, W.M.; Taylor, N.L. 2006. Molecular phylogenetics of the clover genus (Trifolium - Leguminosae). Molecular Phylogenetics and Evolution 39: 688-705.

Elshire, R.J.; Glaubitz, J.C.; Sun, Q.; Poland, J.A.; Kawamoto, K.; Buckler, E.S.; Mitchell, S.E. 2011. A robust, simple genotyping-by-sequencing (GBS) approach for high diversity species. PloS ONE 6: e19379.

Ghamkhar, K.; Faithful, T.; Bidhuyut, B.; Nichols, P.; Ryan, M. 2016. Subterranean clover and biserrula for New Zealand's hill country. Grassland Research and Practice Series 16: 299-308. 
Ghamkhar, K.; Isobe, S.; Nichols, P.H.; Faithfull, T.; Ryan, M.; Snowball, R.; Sato, S.; Appels, R. 2012. The first genetic maps for subterranean clover (Trifolium subterraneum L.) and comparative genomics with T. pratense L. and Medicago truncatula Gaertn. to identify new molecular markers for breeding. Molecular Breeding 30: 213-226.

Ghamkhar, K.; Nichols, P.; Erskine, W.; Snowball, R.; Murillo, M.; Appels, R.; Ryan, M. 2015. Hotspots and gaps in the world collection of subterranean clover (Trifolium subterraneum L.). The Journal of Agricultural Science 153: 1069-1083.

Ghamkhar, K.; Revell, C.; Erskine, W. 2013. Biserrula pelecinus L.- genetic diversity in a promising pasture legume for the future. Crop and Pasture Science 63: 833-839.

Gillingham, A.C.; During, C. 1973. Pasture production and transfer of fertility within a long established hill pasture. New Zealand Journal of Experimental Agriculture 1: 227-232.

Guan, X.; Zhang, X.; Turner, N.; Xu, B.; Li, F. 2013. Two perennial legumes (Astragalus adsurgens Pall. and Lespedeza davurica S.) adapted to semiarid environments are not as productive as lucerne (Medicago sativa L.), but use less water. Grass and Forage Science 68: 469-478.

Haling, R.E.; Yang, Z.; Alden, R.; Stefanski, A.; Ryan, M.H.; Kidd, D.R.; Sandral, G.A.; Lambers, H.; Simpson, R.J. 2015. Variation in root foraging traits amongst Trifolium species associated with phosphorus acquisition. International Society of Root Research conference, 6-9 October 2015. Canberra, Australia.

Hayes, B.J.; Cogan, N.O.I.; Pembleton, L.W.; Goddard, M.E.; Wang, J.; Spangenberg, G.C.; Forster, J.W. 2013a. Prospects for genomic selection in forage plant species. Plant Breeding 132: 133-143.

Hayes, B.J.; Lewin, H.A.; Goddard, M.E. 2013b. The future of livestock breeding: genomic selection for efficiency, reduced emissions intensity, and adaptation. Trends in Genetics 29: 206-214.

Heffner, E.L.; Lorenz, A.J.; Jannick, J.-L.; Sorrells, M.E. 2010. Plant breeding with genomic selection: gain per unit time and cost. Crop Science 50: 16811690.

Hosseini, S.; Mofidy Khajeh, A.; Abarsaji, G.; Parsaei, L. 2010. Identification of forage Astragalus in summer rangelands of Golestan province. Journal on Plant Science Research 18: 47-55.

Humphreys, M.; Thomas, H.-M.; Harper, J.; Morgan, G.; James, A.; Ghamari-Zare, A.; Thomas, H. 1997. Dissecting drought- and cold-tolerance traits in the Lolium-Festuca complex by introgression mapping. New Phytologist 137: 55-60.

Hussain, S.W.; Williams, W.M. 2014. Trifolium occidentale: a valuable genetic resource for white clover improvement. Revitalising grasslands to sustain our communities. Proceedings of the 22nd International Grassland Congress. Sydney, Australia.

IPCC 2013. Climate Change 2013: The Physical Science Basis. Contribution of Working Group I to the Fifth Assessment Report of the Intergovernmental Panel on Climate Change. Cambridge University Press, Cambridge, United Kingdom. 1535 pp.

Kerr, G.A.; Brown, J.; Kilday, T.; Stevens, D.R. 2015. A more quantitative approach to pasture renewal. Journal of New Zealand Grasslands 77: 251-258.

Kochian, L.V.; Hoekenga, O.A.; Piñeros, M.A. 2004. How do crop plants tolerate acid soils? Mechanisms of aluminium tolerance and phosphorus efficiency. Annual Review of Plant Biology 55: 459-493.

Kochian, L.V.; Piñeros, M.A.; Liu, J.; Magalhaes, J.V. 2015. Plant adaptation to acid soils: the molecular basis for crop aluminum resistance. Annual Review of Plant Biology 66: 571-598.

Lambert, M.G.; Luscombe, P.C.; Clark, D.A. 1982. Soil fertility and hill country production. Proceedings of the New Zealand Grassland Association 43: 153-160.

Li, X.; Wei, Y.; Acharya, A.; Hansen, J.L.; Crawford, J.L.; Viands, D.R.; Michaud, R.; Claessens, A.; Brummer, E.C. 2015. Genomic prediction of biomass yield in two selection cycles of a tetraploid alfalfa breeding population. The Plant Genome 8: doi:10.3835/plantgenome2014.3812.0090.

Loi, A.; Cocks, P.; Howieson, J.; Carr, S. 1997. Morphological characterization of Mediterranean populations of Biserrula pelecinus L. Plant Breeding 116: 171-176.

Loi, A.; Nutt, B.; Revell, C. 2015. Biserrula. https:// www.agric.wa.gov.au/pasture-establishment/biserrula

MacFarlane, M.J.; Sheath, G.W. 1983. Clover - what types for dry hill country? Proceedings of the New Zealand Grassland Association 45: 140-150.

Malo, J.; Suarez, F. 1995. Cattle dung and the fate of Biserrula pelecinus L. (Leguminosae) in a Mediterranean pasture: seed dispersal, germination and recruitment. Botanical Journal of the Linnean Society 118: 139-148.

Ministry for the Environment 2007. Environment New Zealand 2007. https://www.mfe.govt.nz/sites/ default/files/environment-nz07-dec07.pdf

Moir, J.L.; Moot, D.J. 2014. Medium-term soil pH and exchangeable aluminium response to liming at three high country locations. Proceedings of the New Zealand Grassland Association 76: 41-45.

Nichols, S.N. 2012. Introgression of root and shoot characteristics in Trifolium repens $\times$ Trifolium uniflorum interspecific hybrids. $\mathrm{PhD}$ thesis. Lincoln University, New Zealand. http://hdl.handle. net/10182/5091 
Nichols, S.N.; Crush, J.R.; Ouyang, L. 2014a. Phosphate responses of some Trifolium repens $\times$ Trifolium uniflorum interspecific hybrids grown in soil. Crop and Pasture Science 65: 382-387.

Nichols, S.N.; Hofmann, R.W.; Williams, W.M. 2014b. Drought resistance of Trifolium repens $\times$ Trifolium uniflorum interspecific hybrids. Crop and Pasture Science 65: 911-921.

Nichols, S.N.; Hofmann, R.W.; Williams, W.M. 2015. Physiological drought resistance and accumulation of leaf phenolics in white clover interspecific hybrids. Environmental and Experimental Botany 119: 40-47.

NZ hill country cropping and regrassing network 2003. Establishing Clover and Advanced Grass Species on Hill Country. Report to the Sustainable Farming Fund, Grant number 01/130. 19 pp.

Revell, C.K.; Ewing, M.A.; Nutt, B.J. 2012. Breeding and farming system opportunities for pasture legumes facing increasing climate variability in the south-west of Western Australia. Crop and Pasture Science 63: 840-847.

Rios, J.L.; Waterman, P.G. 1997. A review of the pharmacology and toxicology of Astragalus. Phytotherapy Research 11: 411-418.

Shadnoush, G.; Jouri, M.H.; Askarizadeh, D.; Rahimi Kakroodi, V. 2015. Seasonal changes of nutritive values and digestibility of range forage of Chaharmahal and Bakhtiari Province, Iran. Journal of Rangeland Science 5: 94-104.

Simeão Resende, R.M.; Casler, M.D.; Vilela de Resende, M.D. 2014. Genomic selection in forage breeding: accuracy and methods. Crop Science 54: 143-156.

Simpson, R.J.; Richardson, A.E.; Nichols, S.N.; Crush, J.R. 2014. Pasture plants and soil fertility management to improve the efficiency of phosphorus fertiliser use in temperate grassland systems. Crop and Pasture Science 65: 556-575.

Smetham, M.L. 2003. Subterranean clover (Trifolium subterraneum): its history and current and future research in New Zealand. Legumes for Dryland Pastures. Grassland Research and Practice Series 11: 61-72.

Stevens, D.R.; Lancashire, J.A.; Barker, D.J.; Moloney, S.C.; Pollock, K.; Archie, W.J. 1993. Introduction, production, and persistence of five grass species in dry hill country. 1. Introduction, site descriptions, and general methods. New Zealand Journal of Agricultural Research 36: 1-10.
Stevens, D.R.; Turner, J.D.; Barker, D.J.; Moloney, S. 1989. 'Grasslands Maru' phalaris: Productive and persistent in hill country. Proceedings of the New Zealand Grassland Association 50: 231-236.

Stewart, A.V. 2006. Genetic origins of perennial ryegrass (Lolium perenne) for New Zealand pastures. Advances in Pasture Plant Breeding. Grassland Research and Practice Series 12: 55-61.

Swinny, E.; Revell, C.K.; Campbell, N.; Spadek, E.; Russo, C. 2015. In search of photosensitising compounds in the annual forage legume Biserrula pelecinus L. Crop and Pasture Science 66: 11611166.

Thomas, H.M.; Morgan, W.G.; Humphreys, M.W. 2003. Designing grasses with a future - combining the attributes of Lolium and Festuca. Euphytica 133: 19-26.

Thompson, B.R.; Stevens, D.R. 2011. Pasture and tussock responses to a single application of nitrogen or a full development process for drier hill country over two years. Proceedings of the New Zealand Grassland Association 73: 223-228.

Townsend, C. 1993. Breeding, physiology, culture, and utilization of cicer milkvetch (Astragalus cicer L.). Advances in Agronomy 49: 253-308.

Wheeler, D.M.; Edmeades, D.C.; Christie, R.A.; Gardner, R. 1992. Effect of aluminium on the growth of 34 plant species: A summary of results obtained in low ionic strength solution culture. Plant and Soil 146: 61-66.

Williams, W.M. 2014. Trifolium interspecific hybridisation: widening the white clover gene pool. Crop and Pasture Science 65: 1091-1106.

Williams, W.M.; Sheath, G.W.; Chapman, D.F. 1990. Evaluation of clovers in dry hill country. 1. General objectives and description of sites and plant material. New Zealand Journal of Agricultural Research 33: 521-526.

Woodfield, D.R. 1999. Genetic improvements in New Zealand forage cultivars. Proceedings of the New Zealand Grasslands Association 61: 3-7.

Yang, Z.-B.; Rao, I.M.; Horst, W.J. 2013. Interaction of aluminium and drought stress on root growth and crop yield on acid soils. Plant and Soil 372: 3-25.

Yang, Z.; Culvenor, R.A.; Haling, R.E.; Stefanski, A.; Ryan, M.H.; Sandral, G.A.; Kidd, D.R.; Lambers, H.; Simpson, R.J. 2015. Variation in root traits associated with nutrient foraging among temperate pasture legumes and grasses. Grass and Forage Science In Press. 